\title{
ЗАГАЛЬНА ХАРАКТЕРИСТИКА ДІЯЛЬНОСТІ НАТО ПІСЛЯ 11 ВЕРЕСНЯ 2001 РОКУ
}

Афанасенко С. I.

У статті розглядається Організація Північноатлантичного договору, яка є міжнародною організацією військового напряму, та їі основні напрями діяльності і мета створення на функціонування в історичному контексті. Розглядається базова мета, яка була, $\epsilon$ i буде актуальною, та основні загрози, що мають змінний характер. Наприклад, із масовою терористичною діяльністю у США з'явилася нова загроза, яка є несумісною із миром $і$ безпекою людства. Bперше за 50 років існування НАТО, після події 11 вересня 2001 року у США, 5 cmammя Cmamymy HАTО повинна була бути застосована. Відтоді НАТО активно сприяє протидіi та викриттю міжнародного тероризму. Стають актуальними підвищення обміну інформацією та розроблення технологічних рішень по лінії програми роботи із захисту від тероризму та програми «Наука заради миру і безпеки». Зокрема, розроблення певних програм у проблемі тероризму, а саме «Програми з дистанційного виявлення вибухових речовин», «Активних зусиль» та інших. Внесок НАТО у те, що, безумовно, є тривалою та важкою боротьбою, відображає порівняльні переваги Альянсу та спирається на його наявну експертизу. Тероризм $\epsilon$ прямою загрозою безпеці громадян країн НАТО, міжнародній стабільності і процвітанню в ширшому плані та буде залишатися загрозою в найближчому майбутньому. НАТО у своїх стратегіях розробляє нові можливості та технології для подолання терористичної загрози та управління наслідками теракту, а також співпрацює з партнерами та міжнародними організаціями, щоб використати повний потенціал кожного зацікавленого учасника глобальної боротьби з тероризмом.

З 2001 року Альянс розробив і сформулював послідовну політику щодо тероризму. Ця політика, викладена в заявах на вищому рівні та в міністерстві, а також у рішеннях Північноатлантичної ради, об'єднує сильне засудження тероризму у всіх його формах, прихильність до єдності та солідарності перед цією загрозою та рішучість боротися $з$ нею як належить. Оскільки терористи прагнуть знищити цінності, які $є$ основою Альянсу, і що ці цінності $\epsilon$ спільними з партнерами, збереження єдності та солідарності має життєво важливе значення для боротьби з тероризмом.

Ключові слова: НАТО, Альянс, тероризм, терористи, устав, статут, безпека, політика, програма.

В статье рассматривается Организация Североатлантического договора, которая является международной организацией военного направления и ее основные направления деятельности и цели создания на функционирование в историческом контексте. Рассматривается базовая цель, которая была, есть и будет актуальной, и основные угрозы, которые имеют переменный характер. Так, с массовой террористической деятельностью в США появилась новая угроза, которая несовместима с миром и безопасностью человечества. Впервые за 50 лет существования НАТО, после события 11 сентября 2001 года в США, 5 статья Устава НАТО должна была быть применена. С тех пор НАТО активно способствует противодействию и разоблачению международного терроризма. Становятся актуальными повышение обмена информацией и разработка технологических решений по линии программы работы по защите от терроризма и программы «Наука ради мира и безопасности». В частно- сти, разработка определенных программ в проблеме терроризма, а именно «Программы по распознаванию взрывчатых веществ», «Активных усилий» и других. Вклад НАТО в том, что, безусловно, является длительной и тяжелой борьбой, отражает сравнительные преимущества Альянса и опирается на его существующую экспертизу. Терроризм является прямой угрозой безопасности граждан стран НАTO, международной стабильности и процветанию в более широком плане и будет оставаться угрозой в ближайшем будущем. НАТО в своих стратегиях разрабатывает новые возможности и технологии для преодоления террористической угрозы и управления последствиями теракта, а также сотрудничает с партнерами и международными организациями, чтобы использовать полный потенциал каждого заинтересованного участника глобальной борьбы с терроризмом.

С 2001 года Альянс разработал и сформулировал последовательную политику в отношении терроризма. Эта политика, изложенная в заявлениях на высшем уровне и в министерстве, а также в решениях Североатлантического совета, объединяет сильное осуждение терроризма во всех его формах, приверженность к единству и солидарности перед этой угрозой и решимость бороться с ней как нужно. Поскольку террористы стремятся уничтожить ценности, которые являются основой Альянса, и что эти ченности являются общими с партнерами, сохранение единства и солидарности имеет жизненно важное значение для борьбы с терроризмом.

Ключевые слова: НАТО, Альянс, терроризм, террористы, устав, статут безопасность, политика, программа.

The article examines the North Atlantic Treaty Organization, which is an international military organization and its main directions of activity and purpose of creation for operation in a historical context. The main aim that has been, exists and will be relevant and the main threats of changing nature are considered. So, with massive terrorist activities in the United States, there is a new threat that is incompatible with the peace and security of mankind. For the first time during 50 years of NATO's existence, after 11, September, 2001, in the USA, the Article 5 of the NATO Charter had to be applied. Since then, NATO has been actively contributing to counter and denounce international terrorism. Increasing information exchange and development of technological solutions through the work program on protection against terrorism and the program "Science for Peace and Security" are becoming relevant, development of specific programs on the problem of terrorism "Remote Explosives Detection Program", "Active Efforts" and others. The contribution of NATO to what is certainly a long and hard struggle reflects the comparative advantages of the Alliance and is based on its existing expertise. Terrorism is a direct threat to the security of the citizens of NATO countries, international stability and prosperity in the broad sense and will remain a threat to foreseeable future. NATO in its strategies develops new opportunities and technologies to overcome the terrorist threat and manage the consequences of the terrorist attack, and also collaborates with partners and international organizations to use the full potential of each stakeholder in the global fight against terrorism. 
Consequently, since 2001, the Alliance has developed and formulated a consistent policy on terrorism. This policy, set out in statements at the highest level and in the ministry, as well as in the decisions of the North Atlantic Council, brings together a strong condemnation of terrorism in all its forms, a commitment to unity and solidarity in the face of this threat, and the determination to fight it as needed. Since terrorists seek to destroy the values that are the foundation of the Alliance and that these values are shared with partners, the preservation of unity and solidarity is vital to the fight against terrorism. The contribution of NATO to what is certainly a long and hard struggle reflects the comparative advantages of the Alliance and is based on its existing expertise. An example of cooperation in the area of terrorism is the "Remote Explosives Detection Program". At the same time, taking into account the multifaceted nature of the threat, cooperation with partner countries and other international organizations has become a key aspect of NATO's approach to terrorism. Terrorism is a permanent item on the agenda of both the North Atlantic Council and the Euro-Atlantic Partnership Council. Regular terrorism consultations between allies and partners and other organizations contribute to joint assessment and concerted action, thereby helping to ensure a united international response to the fight against terrorism. All the same, in order to finally combat terrorism, the whole international community must act.

Key words: NATO, Alliance, terrorism, terrorists, charter, security, politics, program.

Постановка проблеми та іï актуальність. Метою створення НАТО, відповідно до уставу $\epsilon$ об'єднання своїх зусиль з метою створення колективної оборони і збереження миру і безпеки. Тероризм, як один із напрямів діяльності, які постягаються на мир та безпеку людства існує давно, але міжнародного характеру він набрав саме, після 11 вересня 2001 року, та особливо історично закріпився у Організації Північноатлантичного договору, та поставив нові цілі для цієї організації.

Коли НАТО, тільки було створене, перший генеральний секретар зазначав, що метою даної організації за словами першого генерального секретаря Ісмей Гастингса, мета створення НАТО: «... утримувати російських осторонь, американців - усередині, а німців - під»[1, с. 23], тобто направлена проти агресії Радянського союзу. Після розпаду радянського союзу, НАТО відійшло від цієї мети, але після спливу революції Гідності на Україні, НАТО у 2015 році закріпило Росію основною загрозою безпеці для НАТО, а її стримування офіційно проголошено новою місією НАТО. Натомість глава військового відомства РФ Шойгу С., зазначив, що «Головний ворог - це міжнародний тероризм. Може це банальна фраза, яка приїлася, але подивіться, хто воює в Сирії, в Афганістані, в Малі, в Лівії. Друге - це наближення НАТО до наших кордонів ». Також, НАТО у 2002 році закріпила стратегію по боротьбі із тероризмом, саме визначаючи ії як загрозу миру та людству.

Метою статті $\epsilon$ розгляд діяльності НАТО після 11 вересня 2001 року.

Виклад основного матеріалу. Хоча ще в 1998-2000 рр. американські громадяни і американська власність піддавалися терористичним атакам (вибухи американських посольств в Кенії і Танзанії і напад терористів на есмінець США «Коул»), корінні зміни в антитерористичній стратегії США відбулися після атаки на Всесвітній торговий центр і Пентагон. Регіональні проблеми, включаючи тероризм, етнічні конфлікти, торгівлю наркотиками і незаконну мігра- цію, які представляли раніше загрози в основному країнам СНД, НАТО тепер стало розглядати як виклик безпеки всім країнам - членам Альянсу.

Уперше за 50 років існування НАТО, після події 11 вересня 2001 році у США 5 стаття Статуту НАТО повинна була бути застосована. Під вечір США отримало одноголосну підтримку країн членів НАТО. 4 жовтня 2001 року, після того, як було визначено, що терористичні напади 11 вересня на Нью-Йорк і Вашингтон були здійснені з-за кордону, НАТО ухвалила пакет з восьми заходів, спрямованих на підтримку Сполучених Штатів Америки. За запитом США вона розпочала першу в своїй історії операцію з боротьби з тероризмом «Ігл есіст» сім літаків АВАКС НАТО брали участь у патрулюванні повітряного простору Сполучених Штатів. Операція тривала з середини жовтня 2001 року до середини травня 2002 року. Було залучено 830 членів екіпажів із 13 країн НАТО, які здійснили понад 360 літако-вильотів. Вперше в історії Альянсу його військові сили і засоби були застосовані на підтримку операції, що проводилася відповідно до вимог статті 5 Північноатлантичного договоpy [2, с. 1].

У травні 2002 р в Рейк'явіку зібралися міністри закордонних справ країн-членів НАТО. Саме на цьому саміті була завершена дискусія про так званих «зонах відповідальності» Альянсу. В офіційній заяві після закінчення зустрічі було чітко сказано, що НАТО може проводити військову операцію в будь-якому регіоні світу для боротьби з тероризмом. Це не тільки створювало квазілегальну підставу для операцій в Афганістані та Іраку, а й означало, що трансформація Альянсу перетворила його в організацію з глобальними цілями, що і було підтверджено на саміті в Празі в листопаді 2002 року.

По суті, НАТО вирішило підмінити собою Організацію Об'єднаних Націй. Випадково чи ні, але саме в той період ООН піддалася жорсткій критиці за неефективність і корупцію в рядах їі чиновників.

Заходи, прийняті НАТО у відповідь на тероризм, були багато в чому зумовлені терактами 11 вересня 2001 року, що спонукали країни НАТО розпочати проведення операції «Активні Зусилля», потом трансформована у 2016 році на «Морська стража», також НАТО прийняло Військову концепцію захисту від тероризму (МС472) і приступило до здійснення різних змін в силах i засобах та на інституціональному рівні. За минуле десятиліття НАТО домоглася значного прогресу у важливих для Північноатлантичного союзу областях, таких як операції, підвищення обміну інформацією та розробка технологічних рішень по лінії Програми роботи із захисту від тероризму та програми «Наука заради миру і безпеки». 3 цією метою країни НАТО будуть вигідно використовувати «наскрізні» переваги, якими володіє НАТО, і визначать додаткову цінність вкладу НАТО в більш широкі міжнародні зусилля по боротьбі з тероризмом, докладаються під егідою ООН.

Визначаючи загальний підхід НАТО до проблеми тероризму, країни-члени організації визнають, що основні засоби боротьби з тероризмом знаходяться насамперед у розпорядженні цивільних і судових властей держав. Країни НАТО визнають, що інші міжнародні організації мають мандати і потенціали, які могли б підсилити роботу країн НАТО в галузі боротьби з тероризмом. НАТО буде робити особливий наголос на запо- 
бігання терактам і підвищенні здатності до відновлення нормального функціонування за допомогою участі в національних і міжнародних зусиллях, намагаючись при цьому уникати непотрібного дублювання і дотримуючись принципу взаємодоповнюваності. Чітке керівництво, підвищення координації та велика послідовність зусиль і заходів дозволять НАТО більш ефективно користуватися ресурсами [3, с. 1].

DAT POW (Програма оборони проти тероризму) - унікальна програма, побудована за принципом спільного фінансування. Це швидкий шлях до розвитку можливостей. Під POW DAT індивідуальні країни-члени НАTO з підтримкою та підтримкою з боку інших країн-членів та органів НАТО ведуть проекти з розробки передових технологій або контрзаходів, що відповідають найвимогливішим потребам безпеки перед лицем тероризму. Ця програма була схвалена лідерами НАТО на Стамбульському саміті 2004 р. Для зміцнення внеску Альянсу у боротьбу з тероризмом шляхом розбудови можливостей, підтримки операцій та розвитку партнерських відносин. Розвиток DAT POW керується останніми політичними вказівками, в тому числі Стратегічною концепцією 2010 року, керівними принципами політики НАТО щодо боротьби з тероризмом 2012 року та вказівками щодо посиленої ролі НАТО у міжнародній боротьбі з тероризмом, схваленою лідерами НАТО на їх зустрічі в травні 2017 року.

Практична підтримка також надається країнам-союзникам, які проводять окремі зустрічі та заходи з високим рівнем видимості. Цей вид операції розпочався безпосередньо після 11 вересня з операцією Eagle Assist, яка надавала підтримку раннього попередження в США з жовтня 2001 року по травень 2002 року. Надалі подібна підтримка була надана на зустрічах на високому рівні, таких як ЄС і самітів НАТО, а також на Олімпійських іграх в Афінах, де, крім підтримки раннього попередження на борту повітряних суден, були розгорнуті елементи Батальйону захисту від НАТО. Тероризм не завжди був настільки помітним серед питань безпеки НАТО. Незважаючи на те, що в Стратегічній концепції 1999 року документ, який висвітлює виклики, з якими стикається НАТО, і шляхи їх вирішення, визнали тероризм новою загрозою в епоху після закінчення холодної війни, союзники приділяли мало уваги колективу до цієї проблеми до подій від 11 вересня 2001 року. Було мало політичного обговорення характеру та джерел тероризму або наслідків тероризму для концепцій, політик, структур та можливостей Альянсу. Проте з того часу майже кожен аспект роботи в НАТО був переглянутий з огляду на загрозу тероризму нашим народам та силам [5, ст. 1].

Починаючи з 2012 року періодично проводяться навчання групи «Пильне небо», а в березні 2012-го відбулися КШУ під егідою Ради «Росія-НАТО» за реагуванням на залучення терористів круїзного лайнера. В даний час основні зусилля Північноатлантичного союзу зосереджені на боротьбі з «Ісламським державою Іраку і Леванті». За оцінкою натовських експертів, ця організація володіє значним військовим потенціалом, який дозволяє ісламістам успішно протистояти діям міжнародної корупції та урядовими військами Іраку та Сирії. Разом з тим активність альянсу на даному напрямку обмежується спостереженням ситуації в регіоні, наданням політичної підтримки та сприяння Туреччини у забезпеченні захисту національного повітряного простору, а також наданням деяким країнам регіону консультативної допомоги в сфері безпеки та оборони. Зокрема, над східною частиною акваторії Середземного моря виконуються польоти на літаках ДРЛО Е-3А «Авакс-НАТО», а також задіяна розвідувальна авіація альянсу. Одночасно активується обмін розвідувальної інформацією між державами блоку, а також з країнами-партнерами. Наприкінці 2015 року в Брюсселі було прийнято рішення про продовження терміну дії 2017-го року розміщення на території Туреччини батареї ЗРК «Патріот» ВC Іспанії про організацію безперервного присутності постійних груп ОВМС блоку в Східному Середземному морі, а також про перекидання в Туреччину авіаліній ДРлО Е-3А «Авакс-НАТО». Отже, після терактів у Парижі (13 листопада 2015 року) керівництво Північноатлантичного союзу заявило про можливість задіяти ст. 5 Вашингтонського договору в разі відповідної звернення Франції. Разом з тим деякі держави альянсу висловлюють сумнів у цілеспрямованості такого кроку, що, на їхню думку, може привести до непередбачуваних наслідків для відносин між Заходом та ісламським світом.

Усе сказане вище говорить про те, що НАТО прагне мати в наявності ефективні інструменти протидії терористичній небезпеці і відігравати провідну роль у боротьбі з міжнародним тероризмом там, де він представляє небезпеку для інтересів Заходу. Однак у дійсності все виявилося не зовсім так. Мабуть, що вживаються заходи виявилися недостатньо ефективними. У столиці НАTO та ЄС у Брюсселі 22 березня виникла серія терактів. Два вибухи пройшли в аеропорту бельгійської столиці, ще один-брюссельський метро, в результаті яких 34 людини загинули і 230 отримали вбивство. Наряду з іншими контр терористичними та попереджувальними заходами з столиці були вивезені король Філіп і королева Матильда. Відповідальність за виправдані вибухи взяла на себе терасова група "Ісламське держава", яка загрожує новими акціями у Європі. Ці злочини доводять нездійсненність політики НАТО, повне нерозуміння альянсом міжнародної ситуації, а також факт дезорієнтації громадської думки в Європі, яка, замість реального ворога - міжнародного тероризму, - нав'язує мені, зокрема Росії.

Висновки. Отже, з 2001 року Альянс розробив i сформулював послідовну політику щодо тероризму. Ця політика, викладена в заявах на вищому рівні та в міністерстві, а також у рішеннях Північноатлантичної ради, об'єднує сильне засудження тероризму у всіх його формах, прихильність до єдності та солідарності перед цією загрозою та рішучість боротися з нею як потрібно. Оскільки терористи прагнуть знищити цінності, які $є$ основою Альянсу, і що ці цінності $є$ спільними з партнерами, збереження єдності та солідарності має життєве важливе значення для боротьби з тероризмом. Внесок НАТО у те, що, безумовно, $\epsilon$ тривалою та важкою боротьбою, відображає порівняльні переваги Альянсу та спирається на його наявну експертизу. Прикладом співробітництва у проблемі тероризму $\epsilon$ «Програма з дистанційного виявлення вибухових речовин». Водночас враховуючи багатогранний характер загрози, співпраця з країнами-партнерами та іншими міжнародними організаціями стала ключовим аспектом підходу НАТО до тероризму. Тероризм є постійним пунктом порядку денного як Північноатлантичної ради, так і Ради 
євроатлантичного партнерства. Регулярні консультації з питань тероризму між союзниками та партнерами та іншими організаціями сприяють спільній оцінці та узгодженим діям, відповідно, допомагаючи забезпечити єдину міжнародну реакцію у боротьбі з тероризмом. Все таки, щоб остаточно побороти тероризм необхідно діяти всім міжнародним співтовариством.

\section{Література}

1. Reynolds D. The Origins of the Cold War in Europe: International Perspectives. Yale University Press, 1994. ISBN 0-300-10562-2.

2. Operations and missions: past and present. NATO. 2005. URL: https://www.nato.int/cps/uk/natolive/topics_ 52060.htm.

3. NATO and Terrorism. NATO. 2002. URL: https:// www.nato.int/cps/ic/natohq/official_texts_87905.htm? selectedLocale $=$ ru.
4. Defense Against Terrorism Programme of Work. NATO. 2015. URL: https://www. nato.int/cps/ic/natohq/ topics_50313.htm?selectedLocale=en.

5. NATO's response to terrorism. NATO. 2005. URL: https: / / www. nato.int/docu/review/2005/combatingterrorism/NATO-Response-Terrorism/EN/index.htm.

6. Міжнародне право : навч. Посібник / за ред. М. Буроменського. Київ : Юрінком Інтер, 2005. 336 с.

7. Мала енциклопедія міжнародної безпеки / за заг. ред. Ю. Бошицького, О. Потєхіна. Київ : Вид-во Європейського університету. 2012. 368 с.

8. Грицяк І., Камінська Т. Створення, розширення та діяльність Північноатлантичного Альянсу (НАТО). Вісник Національної академії державного управління при Президентові України. 2009. №3. С. 183-195.

Афанасенко С. І., кандидат юридичних наук, доцент, доцент кафедри державно-правових дисциплін одеського державного університету внутрішніх справ 